\title{
Characterization, Distribution, and Ontogenesis of Adenosine Binding Sites in Cat Visual Cortex
}

\author{
C. Shaw, S. E. Hall, and M. Cynader \\ Departments of Psychology and Physiology and Biophysics, Dalhousie University, Halifax, Nova Scotia, \\ Canada B3H 4J1
}

\begin{abstract}
In vitro autoradiographic techniques were used to characterize binding sites for ${ }^{3} \mathrm{H}$-cyclohexyladenosine (CHA) and ${ }^{3} \mathrm{H}-\mathbf{5}^{\prime}-\mathrm{N}$ ethylcarboxamidoadenosine (NECA) in cat and kitten visual cortex. ${ }^{3} \mathrm{H}-\mathrm{CHA}$ binding sites in adult cat have a $B_{\max }$ of 1363 fmol/mg protein and a $K_{\mathrm{d}}$ of $6.8 \mathrm{~nm}$. Displacement experiments indicate that ${ }^{3} \mathrm{H}-\mathrm{CHA}$ binds to an adenosine receptor similar to the $A_{1}$-adenosine receptor described by other investigators. ${ }^{3} \mathrm{H}-\mathrm{NECA}$ binding sites in adult cat have a $B_{\max }$ of $518 \mathrm{fmol} /$ mg protein and a $K_{\mathrm{d}}$ of $15.4 \mathrm{nM}$. Displacement experiments do not allow us to identify this binding site unambiguously. $B_{\max }$ values increase during postnatal development for both binding sites, peaking in adulthood for ${ }^{3} \mathrm{H}-\mathrm{CHA}$ and at $30 \mathrm{~d}$ for ${ }^{3} \mathrm{H}-$ NECA. $K_{d}$ values show neither consistent nor significant differences during postnatal development for either binding site. ${ }^{3} \mathrm{H}$ CHA and ${ }^{3} \mathrm{H}$-NECA binding sites are concentrated in layers 1-3 and upper layer 5 in the visual cortex of adult cats. These laminar patterns, however, change during postnatal development, showing the densest binding in the deep cortical layers (5 and 6 ) in kittens younger than $30 \mathrm{~d}$ of age and a fairly homogeneous binding in older kittens before achieving the adult distribution.
\end{abstract}

The visual cortex plays a critical role in the analysis of visual signals concerned with form, motion, and depth. The mechanisms by which the cortex processes visual information have been the subject of numerous investigations at the physiological (Hubel and Wiesel, 1962), anatomical (Lund, 1973), and neurochemical (Emson and Hunt, 1979) levels. In particular, the last few years have witnessed a dramatic increase in our understanding of the chemistry of the cortex. Accumulating evidence gathered with immunocytochemical, iontophoretic, and receptor binding techniques has greatly expanded the list of neurotransmitters/neuromodulators that may be active in cerebral cortex, in particular, visual cortex (Emson and Hunt, 1979; Parnavelas and McDonald, 1983). These findings point toward a complex chemical circuitry of neocortex in which various neurotransmitters can modulate each other's actions in a variety of different ways.

One such modulatory substance may be adenosine. This purine derivative decreases the firing rates of both central and peripheral neurons (Phillis and Kostopoulos, 1975; Phillis and Wu, 1981; Stone, 1982; Stone and Perkins, 1979). Adenosine modulates adenylate cyclase activity (Ribeiro et al., 1979; Stone, 1981; Van Calker et al., 1979) and the release of several neu-

\footnotetext{
Received May 20, 1985; revised Feb. 21, 1986; accepted Mar. 18, 1986.

This work was supported by grants from the Medical Research Council (PG29) and National Science and Engineering Research Council (A9939) of Canada to M.C. We thank Professor M. Wilkinson for the generous use of laboratory facilities, L. Colpitts for technical assistance, C. Dore for typing, and Dr. T. White and $W$. MacDonald for helpful comments on the manuscript.

Correspondence should be addressed to $C$. Shaw at the above address.

Copyright (c) 1986 Society for Neuroscience $0270-6474 / 86 / 113218-11 \$ 02.00 / 0$
}

rotransmitters (Fredholm and Hedqvist, 1980; Ginsborg and Hirst, 1972; Harms et al., 1979; Hollins and Stone, 1980; Michaelis et al., 1979; Ribeiro, 1979; Snyder, 1985). There is evidence for at least 2 classes of adenosine receptors in the nervous system (Burnstock, 1978; Londos and Wolff, 1977; Londos et al., 1980; Van Calker et al., 1979). $A_{1}$-adenosine receptors, generally labeled with ${ }^{3} \mathrm{H}$-cyclohexyladenosine (CHA) (Bruns et al., 1980; Goodman and Snyder, 1982; Goodman et al., 1983), may have a presynaptic location on axon terminals (Goodman et al., 1983) and are associated with inhibition of adenylate cyclase activity (Van Calker et al., 1979). ${ }^{3} \mathrm{H}-5^{\prime}-\mathrm{N}$-ethylcarboxamidoadenosine (NECA) may be a more selective agonist of the $\mathrm{A}_{2}$ class of adenosine receptors (Londos and Wolff, 1977; Londos et al., 1980), which are associated with activation of adenylate cyclase (Van Calker et al., 1979) and may have a postsynaptic location. This last point is controversial, however, since ${ }^{3} \mathrm{H}$ NECA can label both $A_{1}$ and $A_{2}$ receptors (Snyder, 1985), and species differences in the subtypes of adenosine receptors have been described (Barnes and Thampy, 1982; Bruns et al., 1980; Murphy and Snyder, 1982).

Our own studies have been directed to the examination of the receptors for various neurotransmitters and neuromodulators thought to be active in the cat visual cortex (for a summary, see Shaw et al., 1984c). These data, gathered primarily with the methods of receptor autoradiography (Snyder, 1984; Young and Kuhar, 1979), have provided information on the characteristics and laminar distributions of the various receptor populations. Special attention has been directed towards the study of receptor alterations during normal postnatal development, since several receptor populations show differing characteristics and/or distributions in infant and adult animals (Shaw et al., 1984a, c, 1985). In these cases, receptor alterations take place during the physiologically defined critical period (Cynader et al., 1980; Hubel and Wiesel, 1970; Olson and Freeman, 1980), the period in the first few months of postnatal life of greatest neuronal plasticity. Our working hypothesis is that alterations of receptor distribution, number, and/or affinity may play a role in the mechanism by which visual exposure modifies cortical function during the critical period.

In the present study, we have examined adenosine binding sites in visual cortex using ${ }^{3} \mathrm{H}-\mathrm{CHA}$ and ${ }^{3} \mathrm{H}-\mathrm{NECA}$ as ligands (Bruns et al., 1980; Goodman et al., 1983). The adenosine binding sites are characterized and their postnatal development charted in terms of number, affinity, and laminar distribution.

While this paper was being revised, a report by Aoki (1985) appeared describing adenosine binding site distribution in normal and dark-reared cats.

\section{Materials and Methods}

Fourteen male colony cats were maintained on a $14 \mathrm{hr} / 10 \mathrm{hr}$ light/dark cycle and were sacrificed at approximately the same time of day $(1600$ 1830). Following an overdose of sodium pentobarbital, they were perfused through the heart with cold $\left(4^{\circ} \mathrm{C}\right)$ phosphate buffer solution (PBS; $0.1 \mathrm{~m}, \mathrm{pH} 7.4$ ). In some animals, the PBS was followed by a $0.1-0.2 \%$ 
formaldehyde/PBS solution in order to lightly fix the tissue. This procedure had no discernible effect on the characteristics of adenosine binding sites. The brains were quickly removed and frozen in liquid Freon. Sixteen micron coronal sections were cut on a cryostat and thawmounted onto subbed glass slides, then stored at -20 to $-25^{\circ} \mathrm{C}$ until used. In experiments designed to compare animals of different ages, sections were cut within the same $24 \mathrm{hr}$ period and stored for the same length of time before being used.

${ }^{3} \mathrm{H}-\mathrm{CHA}$ (New England Nuclear; specific activity, $25 \mathrm{Ci} / \mathrm{mmol}$ ), an adenosine agonist, was used to study binding at $\mathrm{A}_{1}$-adenosine binding sites, and ${ }^{3} \mathrm{H}-\mathrm{NECA}$ (New England Nuclear; specific activity, $30 \mathrm{Ci}$ / mmol) was employed in an attempt to label both $A_{1}$ and $A_{2}$ binding sites.

The slide-mounted sections were allowed to warm to $4^{\circ} \mathrm{C}$. The slides were then preincubated for $10 \mathrm{~min}$ in dishes containing $4^{\circ} \mathrm{C}$ Tris- $\mathrm{HCl}$ buffer ( $50 \mathrm{~mm}, \mathrm{pH} 7.7$ ). A small amount of formaldehyde $(0.2 \%)$ was added to lightly fix the tissue. Two additional $5 \mathrm{~min}$ washes in buffer alone removed the formaldehyde. Reduction of endogenous adenosine was accomplished through the addition of adenosine deaminase, Sigma type VIII (Goodman and Snyder, 1982), to all 3 preincubation rinses at a concentration of $0.06 \mathrm{IU} / \mathrm{ml}$. In preliminary experiments we determined that raising the preincubation concentration of adenosine deaminase to $1 \mathrm{IU} / \mathrm{ml}$ gave, at most, $20 \%$ higher binding. For this reason, preincubation rinses contained the lower concentration. All incubation media, however, contained adenosine deaminase at a concentration of $1 \mathrm{IU} / \mathrm{ml}$ (Goodman and Snyder, 1982). After the preincubation washes, the slides were laid out on a black plastic tray to aid visualization of the sections. The incubation medium containing the tritiated ligand (0.4-52 nM for both ligands) was dripped onto the sections. Nonspecific binding was determined by including $1 \times 10^{-4} \mathrm{M} \mathrm{CHA}$ or L-PIA for ${ }^{3} \mathrm{H}-$ $\mathrm{CHA}$ or ${ }^{3} \mathrm{H}-\mathrm{NECA}$, respectively, to the incubation medium. Incubations for both ligands were for $120 \mathrm{~min}$ at $23^{\circ} \mathrm{C}$. The incubations were terminated with two $5 \mathrm{~min}$ washes in $4^{\circ} \mathrm{C}$ buffer. In characterization studies, areas 17-19 identified from the cortical maps of Tusa et al. (1981) were scraped off the slides onto Whatman GB/F filter paper, suspended in Aquasol II and the bound ligand was counted in a scintillation counter. For autoradiography, sections were incubated at optimal conditions as determined in the characterization experiments. The sections were dried under a stream of cool air, allowed to dry further for at least $12 \mathrm{hr}$ over desiccant at $4^{\circ} \mathrm{C}$, and then apposed to LKB tritium-sensitive Ultrofilm for $1-4$ weeks. The film was conventionally developed and fixed.

Protein content was determined in alternate sections from each animal using the methods of Lowry et al. (1951) and used for computing $B_{\max }$ values. Saturation binding data were analyzed by Eadie-Hofstee plots as described by Zivin and Waud (1982). Cortical lamination was determined for comparison with the autoradiograms by staining alternate sections with cresyl violet or processing for cytochrome $\mathrm{C}$ oxidase activity (Wong-Riley, 1979).

\section{Results}

Characterization of adenosine binding sites using ${ }^{3} \mathrm{H}-\mathrm{CH} A$ and ${ }^{3} \mathrm{H}-\mathrm{NECA}$

Figures 1 and 2 illustrate biochemical experiments in which we characterized the binding sites for ${ }^{3} \mathrm{H}-\mathrm{CHA}$ and ${ }^{3} \mathrm{H}-\mathrm{NECA}$, respectively. For each experiment, each point represents at least 3 separate determinations for total binding. Determination of nonspecific binding was always performed in duplicate. All experiments for these characterizations were performed at least twice. All time course and displacement curves thus represent average values for 2 or more experiments.

Figure 1. Top, Measurements of association and dissociation time constants for ${ }^{3} \mathrm{H}-\mathrm{CHA}$ binding sites in the visual cortex (areas 17-19) of an adult cat. Incubation was at $23^{\circ} \mathrm{C}$ with $9 \mathrm{nM}^{3} \mathrm{H}-\mathrm{CHA}$. Total binding values $(T B)$ are given for the association points, while total, specific $(S B)$, and nonspecific $(N S B)$ valucs are shown for the dissociation points. For association rate measurements, the rinse was for $1 \mathrm{~min}$. Arrow indicates the beginning of the postincubation rinse. Two $5 \mathrm{~min}$ rinses were adopted for subsequent autoradiographic studies. This rinse time left the specific binding quite high while virtually eliminating nonspecific
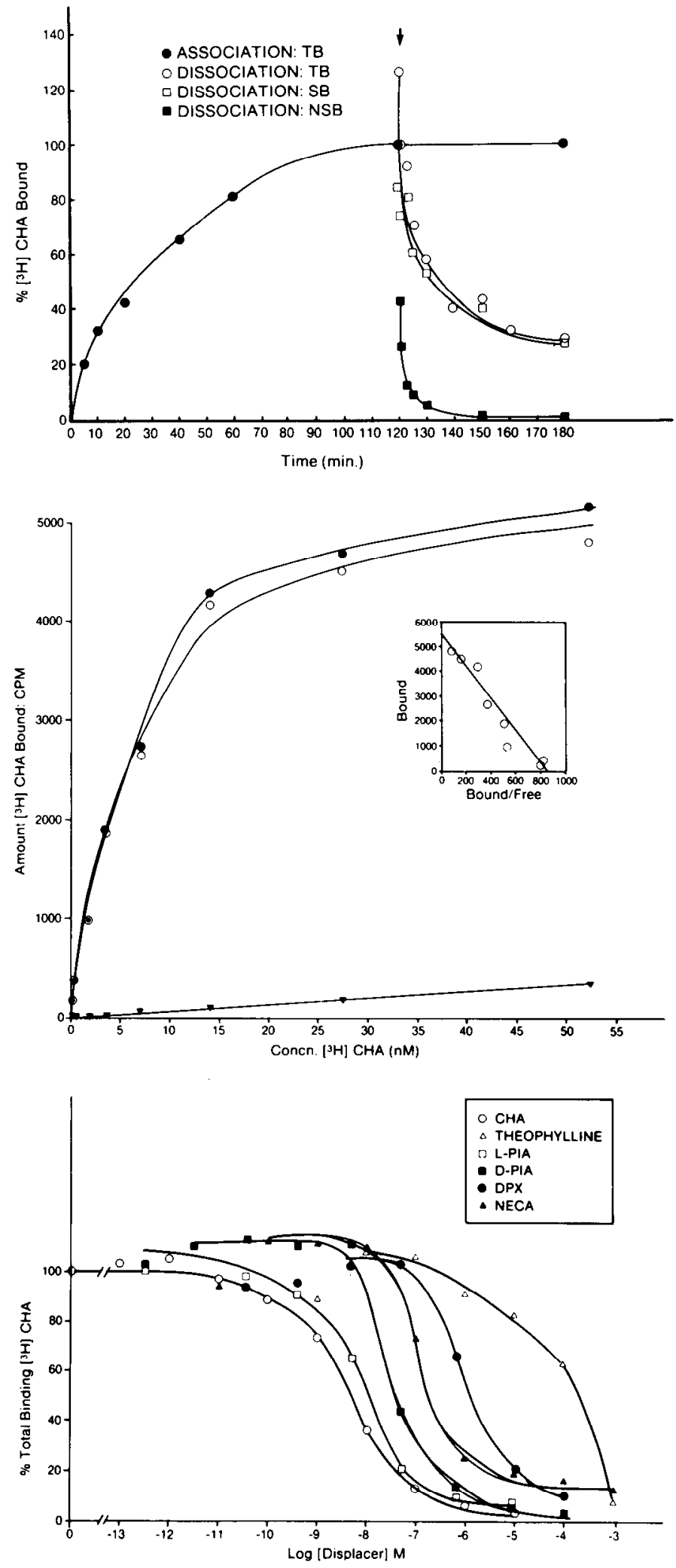

binding. Center, Saturation binding for ${ }^{3} \mathrm{H}-\mathrm{CHA}$ in the visual cortex (areas 17-19) of an adult cat. The ${ }^{3} \mathrm{H}-\mathrm{CHA}$ incubation was for $120 \mathrm{~min}$ at $23^{\circ} \mathrm{C}$. Nonspecific binding was measured by coincubation of alternate sections with $1 \times 10^{-4} \mathrm{M}$ unlabeled CHA. Filled circles, total binding; open circles, specific binding; triangles, nonspecific binding. Inset, Eadie-Hofstee plot. Bottom, Displacement studies for ${ }^{3} \mathrm{H}-\mathrm{CHA}$ in the visual cortex (areas 17-19) of an adult cat. $\mathrm{IC}_{50}$ values are given in Table 1. Incubation in each case was in $20 \mathrm{nM}{ }^{3} \mathrm{H}-\mathrm{CHA}$ for $120 \mathrm{~min}$ at $23^{\circ} \mathrm{C}$ with the appropriate displacers present. 

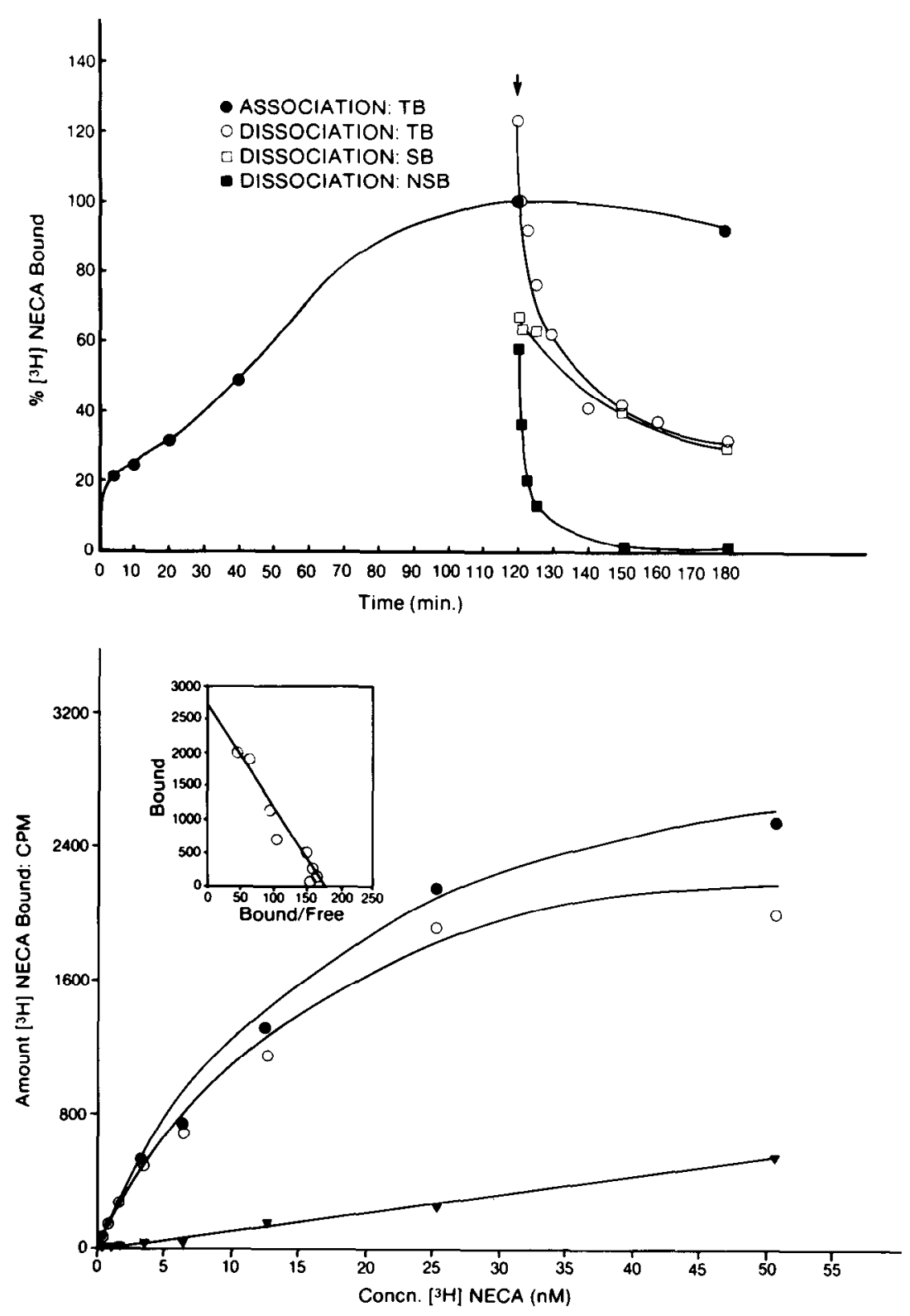

Figure 2. Top. Time constant measurements for ${ }^{3} \mathrm{H}$-NECA binding sites in the visual cortex (areas 17-19) of an adult cat. Incubation was at $23^{\circ} \mathrm{C}$ using $8 \mathrm{~nm}{ }^{3} \mathrm{H}$-NECA. All other details as in Figure 1. Center, Saturation binding for ${ }^{3} \mathrm{H}-\mathrm{NECA}$ in the visual cortex (areas 17-19) of an adult cat. The ${ }^{3} \mathrm{H}-\mathrm{NECA}$ incubation was for 120 $\min$ at $23^{\circ} \mathrm{C}$. Nonspecific binding was measured by coincubation of alternate sections with $1 \times 10^{-4} \mathrm{M}$ L-PIA. Filled circles, total binding; open circles, specific binding; triangles, nonspecific binding. Inset, Eadie-Hofstee plot. Bottom, Displacement studies for ${ }^{3} \mathrm{H}-\mathrm{NECA}$ in the visual cortex (areas 17-19) of an adult cat. IC $C_{50}$ values are given in Table 1. Incubation in each case was in $20 \mathrm{nM}{ }^{3} \mathrm{H}-\mathrm{NECA}$ for 120 min at $23^{\circ} \mathrm{C}$ with the appropriate displacers present.

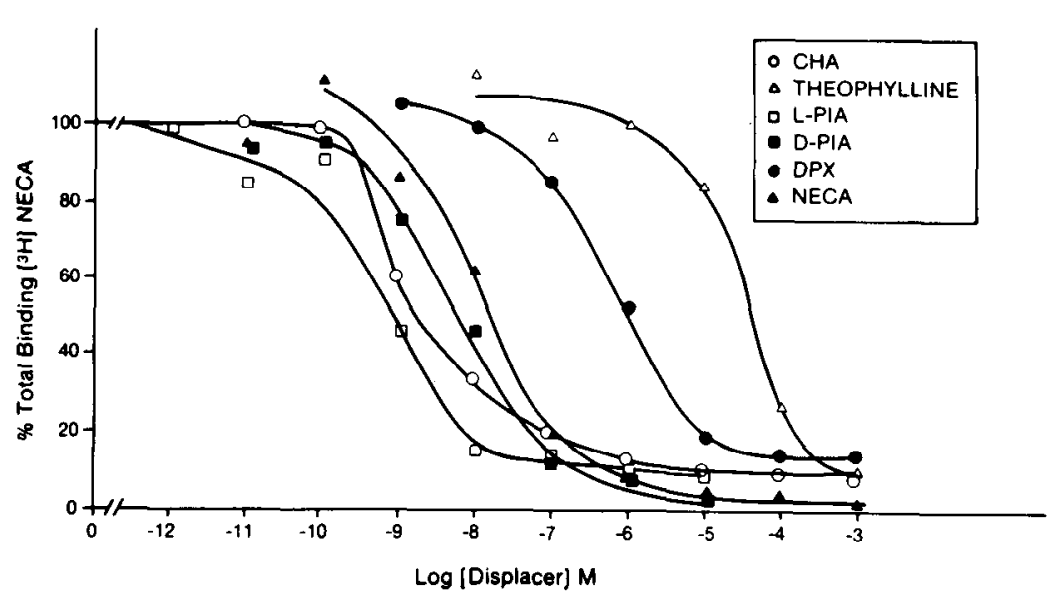

The time course of association and dissociation was examined for ${ }^{3} \mathrm{H}$-CHA binding (Fig. 1, top panel). At $23^{\circ} \mathrm{C}$, equilibrium binding was achieved by $120 \mathrm{~min}$, remaining stable for at least another hour. The association rate constant $\left(K_{+1}\right)$ was cal- culated to be $2.06 \times 10^{-3} \mathrm{~min}^{-1} \mathrm{nM}^{-1}$. Rinsing the sections in an "infinite" dilution led to a rapid decline in specific binding over $10 \mathrm{~min}$, followed by a slower decline. The dissociation rate constant $\left(K_{-1}\right)$ was calculated to be $1.93 \times 10^{-2} \mathrm{~min}^{-1}$. The 


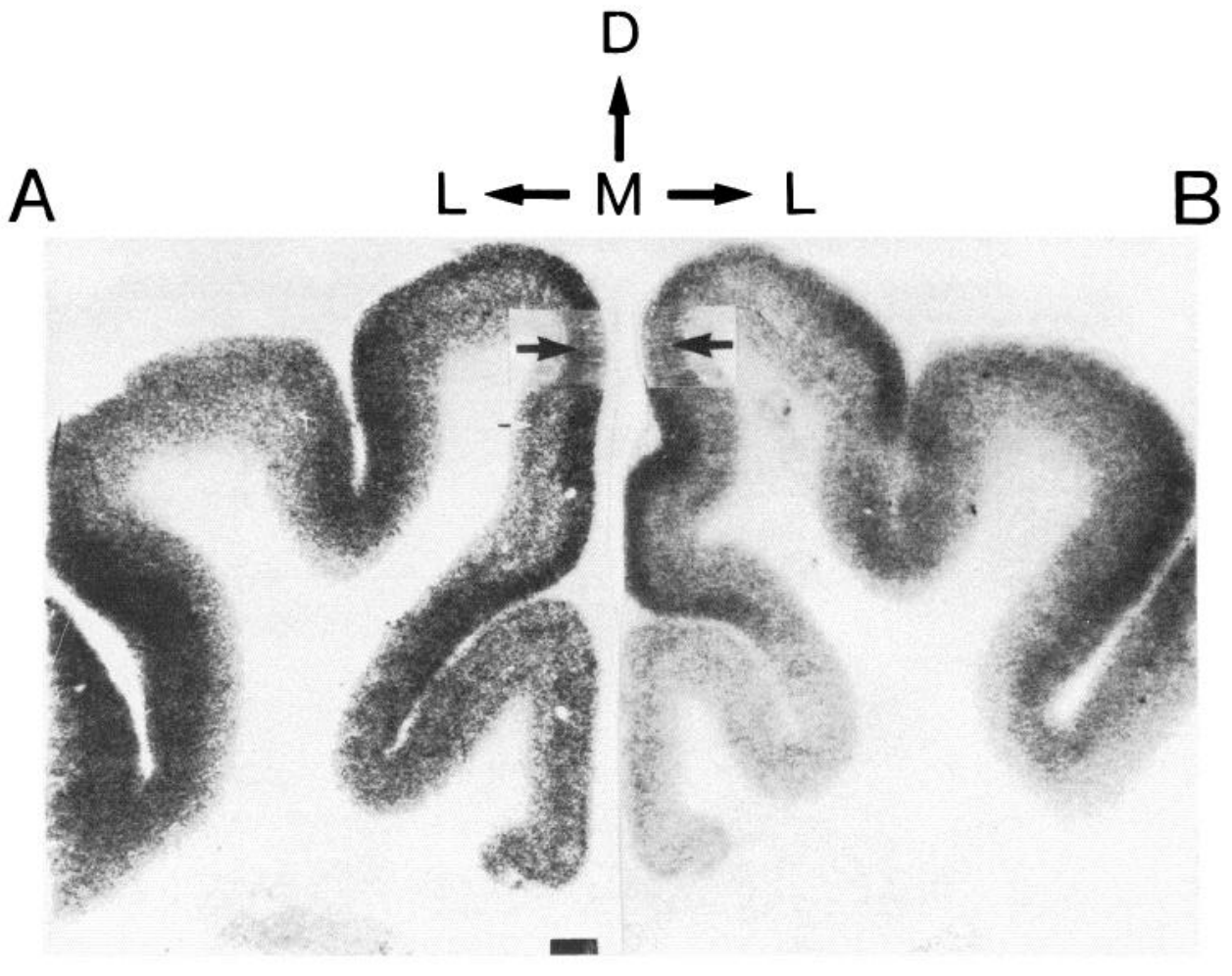

Figure 3. Laminar binding patterns for ${ }^{3} \mathrm{H}-\mathrm{CHA}(A)$ and ${ }^{3} \mathrm{H}-\mathrm{NECA}(B)$ in the visual cortex of adult cats. In both cases, incubation was for $120 \mathrm{~min}$ at $23^{\circ} \mathrm{C}$. Ligand concentrations were 26 $\mathrm{nM}(A)$ and $30 \mathrm{nM}(B)$; exposure period for LKB Ultrofilm was $14 \mathrm{~d}(A)$ and $21 \mathrm{~d}(B)$. Adjacent sections in each instance were processed for cytochrome c oxidase activity (Wong-Riley, 1979). Photographs of the autoradiograms and the cytochrome c-stained sections were made to the same magnification. A portion of a photograph of a cytochrome c-stained section (medial bank of area 17) has been superimposed on the photograph of the autoradiogram. Dark arrows indicate layer 4 which stains most densely for cytochrome c oxidase; white arrow in $A$ points to the labeled sublayer in layer 5 . Calibration bar, 1 $\mathrm{mm}$. Dorsal $(D)$ and medial $(M)$ directions are as indicated.

ratio of these rate constants gave a $K_{\mathrm{d}}\left(=K_{-1}-1 / K_{+1}+1\right)$ of 9.34 nM.

A representative saturation binding experiment for ${ }^{3} \mathrm{H}-\mathrm{CHA}$ is illustrated in Figure 1 (middle panel). Increasing the concentration of ${ }^{3} \mathrm{H}-\mathrm{CHA}$ resulted in saturable binding. Nonspecific binding was less than $7 \%$ of total binding at the highest ligand concentration used. Total binding is represented by filled circles, while specific and nonspecific binding are indicated by open circles and triangles, respectively. Eadie-Hofstee analysis of these data (insert) gave a $B_{\max }$ of $1363.17 \pm 89.04 \mathrm{fmol} / \mathrm{mg}$ protein and a $K_{\mathrm{d}}$ of $6.83 \pm 0.7 \mathrm{nM}$. A Hill plot of these data had a slope of 1.02 , suggesting the existence of a single population of binding sites.

Figure 1 (bottom panel) illustrates a series of displacement experiments in which we determined the $\mathrm{IC}_{50}$ (concentration required to displace $50 \%$ of the bound ${ }^{3} \mathrm{H}-\mathrm{CHA}$ ) for various agonists and antagonists of adenosine. CHA had the lowest value of the compounds tested, with an $\mathrm{IC}_{50}$ of $5 \times 10^{-9} \mathrm{M}$. This value is in good agreement with the previously determined $K_{\mathrm{d}}$ 's derived from the rate constant measurements and with other reports in the literature (Aoki, 1985; Bruns et al., 1980). The $\mathrm{IC}_{50}$ values for all of the compounds tested are shown in Table 1 . The order of potency of the various compounds suggests that ${ }^{3} \mathrm{H}$-CHA labels a binding site similar to the $\mathrm{A}_{1}$-adenosine receptor described by other investigators in other preparations (Bruns et al., 1980).

Figure 2 illustrates the association and dissociation time courses for binding sites labeled with ${ }^{3} \mathrm{H}$-NECA (top panel). At $23^{\circ} \mathrm{C},{ }^{3} \mathrm{H}-\mathrm{NECA}$ binding reached equilibrium by $120 \mathrm{~min}$, remaining relatively stable for at least another hour. The association rate constant was calculated to be $7.66 \times 10^{-4} \mathrm{~min}^{-1} \mathrm{nM}^{-1}$, almost 3 times slower than the $K_{+1}$ for ${ }^{3} \mathrm{H}-\mathrm{CHA}$. Postincubation rinses produced a rapid early decline in specific binding over $10 \mathrm{~min}$, followed by a slower decline that was similar to that described above for ${ }^{3} \mathrm{H}-\mathrm{CHA}$. The dissociation rate constant was calculated to be $1.51 \times 10^{-2} \mathrm{~min}^{-1}$, a value close to that for ${ }^{3} \mathrm{H}-\mathrm{CHA}$. The $K_{\mathrm{d}}$ calculated from these rate constants was
19.71 nM. In Figure 2 (middle panel) the results of a representative saturation binding experiment using ${ }^{3} \mathrm{H}-\mathrm{NECA}$ are illustrated. Specific binding was saturable. Eadie-Hofstee analysis (insert) gave a $B_{\max }$ of $517.77 \pm 7.05 \mathrm{fmol} / \mathrm{mg}$ protein and a $K_{\mathrm{d}}$ of $15.41 \pm 1.84 \mathrm{nM}$. Nonspecific binding was about $25 \%$ of total binding at the highest concentration. A Hill plot of these data gave a slope of 1.02, suggesting the presence of a single population of binding sites.

In Figure 2 (bottom panel) a series of displacement experiments is shown (see also Table 1) using ${ }^{3} \mathrm{H}-\mathrm{NECA}$. NECA had an $\mathrm{IC}_{5_{0}}$ of $14 \mathrm{nM}$, in very good agreement with the $2 K_{\mathrm{d}}$ values determined above for ${ }^{3} \mathrm{H}-\mathrm{NECA}$. The relative potencies of the various displacers for ${ }^{3} \mathrm{H}-\mathrm{NECA}$ resembled those for ${ }^{3} \mathrm{H}-\mathrm{CHA}$ with exceptions only in the order of potency of CHA and L-PIA. These observations were repeated in several experiments. Their similar displacement profiles raise the question of whether ${ }^{3} \mathrm{H}$ CHA and ${ }^{3} \mathrm{H}-\mathrm{NECA}$ are labeling separate binding sites. This issue is further addressed in the Discussion.

Both the binding sites labeled by ${ }^{3} \mathrm{H}-\mathrm{CHA}$ and ${ }^{3} \mathrm{H}-\mathrm{NECA}$ were

Table 1. $\mathrm{IC}_{50}$ values (M) of various adenosine analogs displacing ${ }^{3} \mathrm{H}-\mathrm{CHA}$ and ${ }^{3} \mathrm{H}-\mathrm{NECA}$

\begin{tabular}{lcc} 
Displacer & $\begin{array}{l}{ }^{3} \mathrm{H}-\mathrm{CHA} \\
\text { binding sites }\end{array}$ & $\begin{array}{l}{ }^{3} \mathrm{H}-\mathrm{NECA} \\
\text { binding sites }\end{array}$ \\
\hline CHA & $5 \times 10^{-9}$ & $1.6 \times 10^{-9}$ \\
L-PIA & $1 \times 10^{-8}$ & $8 \times 10^{-10}$ \\
D-PIA & $4 \times 10^{-8}$ & $5.6 \times 10^{-9}$ \\
NECA & $1.6 \times 10^{-7}$ & $1.4 \times 10^{-8}$ \\
DPX & $1 \times 10^{-6}$ & $1 \times 10^{-6}$ \\
Theophylline & $3 \times 10^{-4}$ & $4 \times 10^{-5}$
\end{tabular}

Displacement experiments were performed for ${ }^{3} \mathrm{H}-\mathrm{CHA}$ and ${ }^{3} \mathrm{H}-\mathrm{NECA}$ using various adenosine analogs. The numbers shown represent $\mathrm{IC}_{50}$ values (the concentration required to displace $50 \%$ of total binding) for each compound. PIA, phenylisopropyl adenosine; DPX, 1,3 diethyl-8-phenylxanthine. 
A

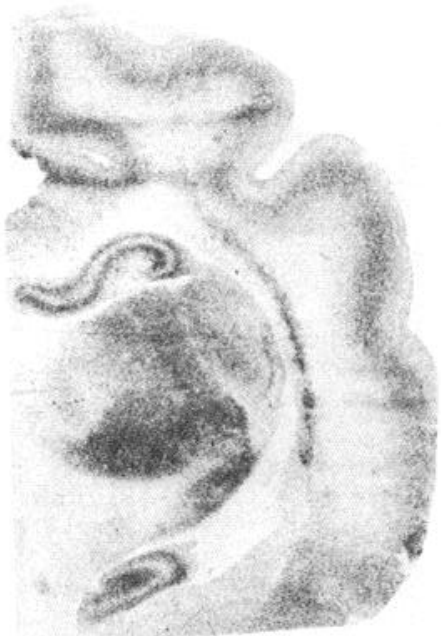

B

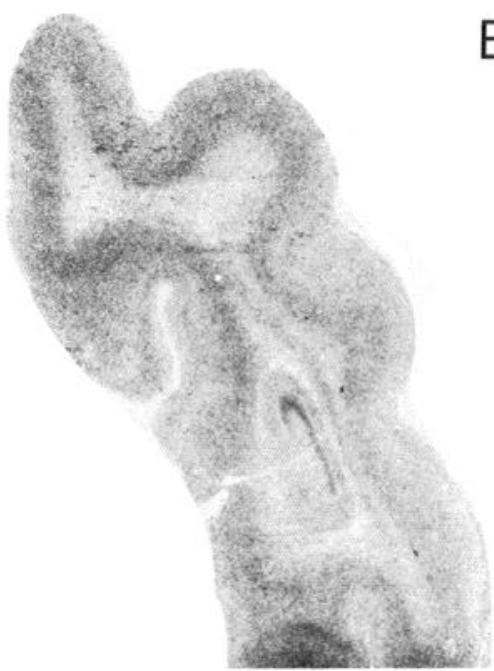

D

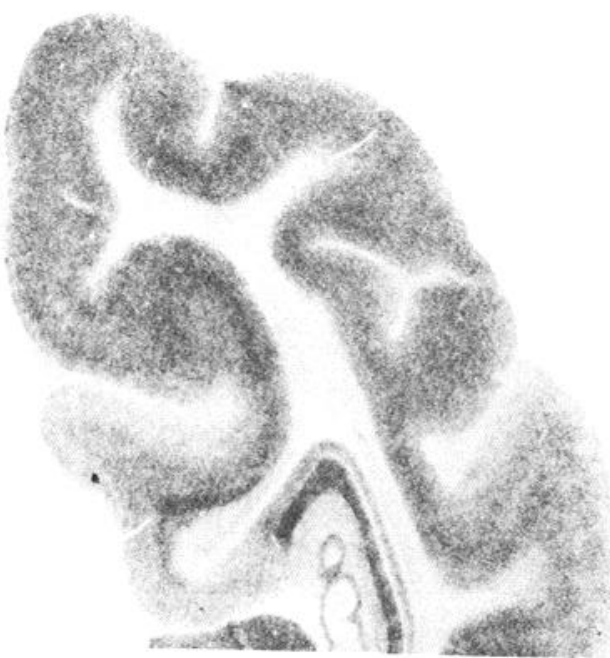

E

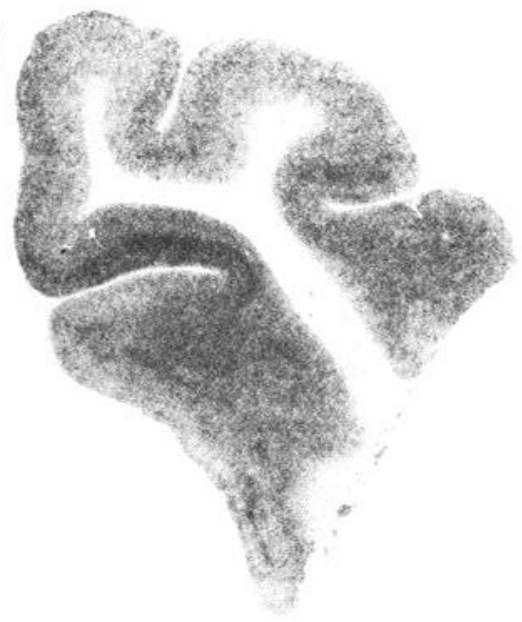

C

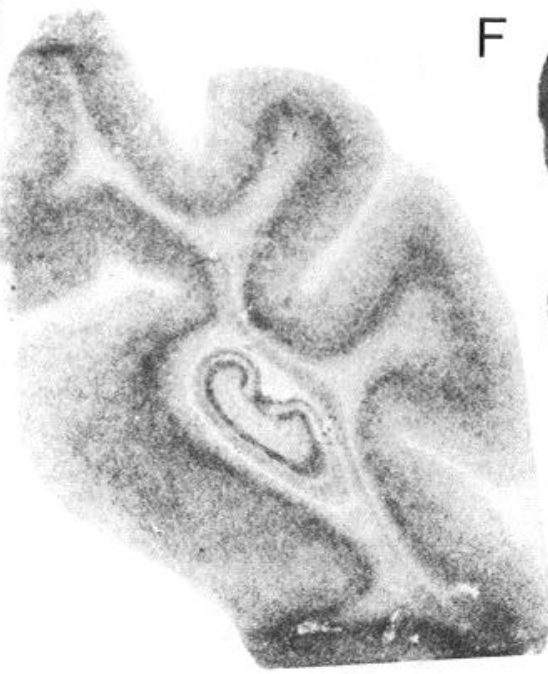

Figure 4. Distribution of ${ }^{3} \mathrm{H}-\mathrm{CHA}$ binding sites in the visual cortex of cats of different postnatal ages: $A, 3$ d; $B, 15 \mathrm{~d} ; C, 30 \mathrm{~d} ; D, 60 \mathrm{~d} ; E, 95 \mathrm{~d}$; $F$, adult. Ligand concentration, $26 \mathrm{~nm}$. Photographs are from LKB Ultrofilm autoradiograms photographed for actual contrast; film exposure, $14 \mathrm{~d}$. Note the changes in laminar distribution during development, from deep layers in the young kittens to superficial layers in adults. For each cat the different laminae were identified in alternate sections stained with cresyl violet or cytochrome c oxidase. Calibration (all panels), $1 \mathrm{~mm}$. Dorsal is up, medial is left for all panels. impervious to additions of up to $1 \times 10^{-6} \mathrm{M}$ dipyridamole, a blocker of facilitated diffusion of adenosine into cells (Wu et al., 1981). Neither the number of binding sites, nor their laminar distributions, was altered for either ligand. These data suggest that neither ${ }^{3} \mathrm{H}-\mathrm{CHA}$ nor ${ }^{3} \mathrm{H}-\mathrm{NECA}$ is labeling high-affinity adenosine transport sites in cat visual cortex.
Distributions of ${ }^{3} \mathrm{H}-\mathrm{CHA}$ and ${ }^{3} \mathrm{H}-\mathrm{NECA}$ binding sites in cat visual cortex

The laminar binding patterns for ${ }^{3} \mathrm{H}-\mathrm{CHA}$ and ${ }^{3} \mathrm{H}-\mathrm{NECA}$ are illustrated in Figure 3. These photographs of the autoradiograms have been combined with inserted slices of photographs from 

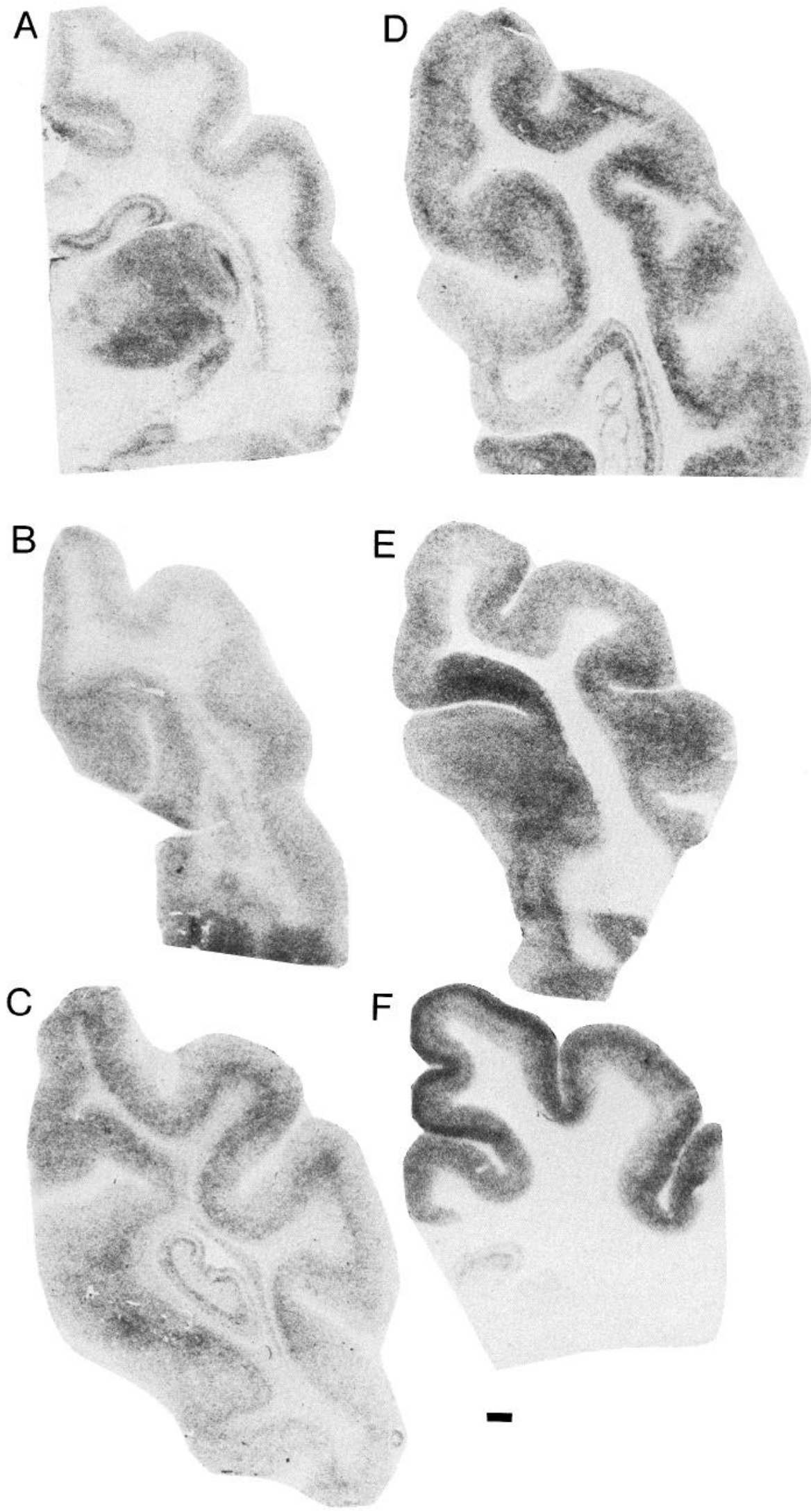

Figure 5. Distribution of ${ }^{3} \mathrm{H}-\mathrm{NECA}$ binding sites in the visual cortex of cats of different postnatal ages: $A, 3$ d; $B, 15 \mathrm{~d} ; C, 30 \mathrm{~d} ; D, 60 \mathrm{~d} ; E, 95 \mathrm{~d}$; $F$, adult. Ligand concentration, $30 \mathrm{~nm}$. Photographs are from LKB Ultrofilm autoradiograms photographed for actual contrast; film exposure, $21 \mathrm{~d}$. Changes in laminar distribution are similar to those seen for ${ }^{3} \mathrm{H}-\mathrm{CHA}$ binding sites (see Fig. 4). Calibration (all panels), $1 \mathrm{~mm}$. Dorsal is up, medial is left for all panels. 


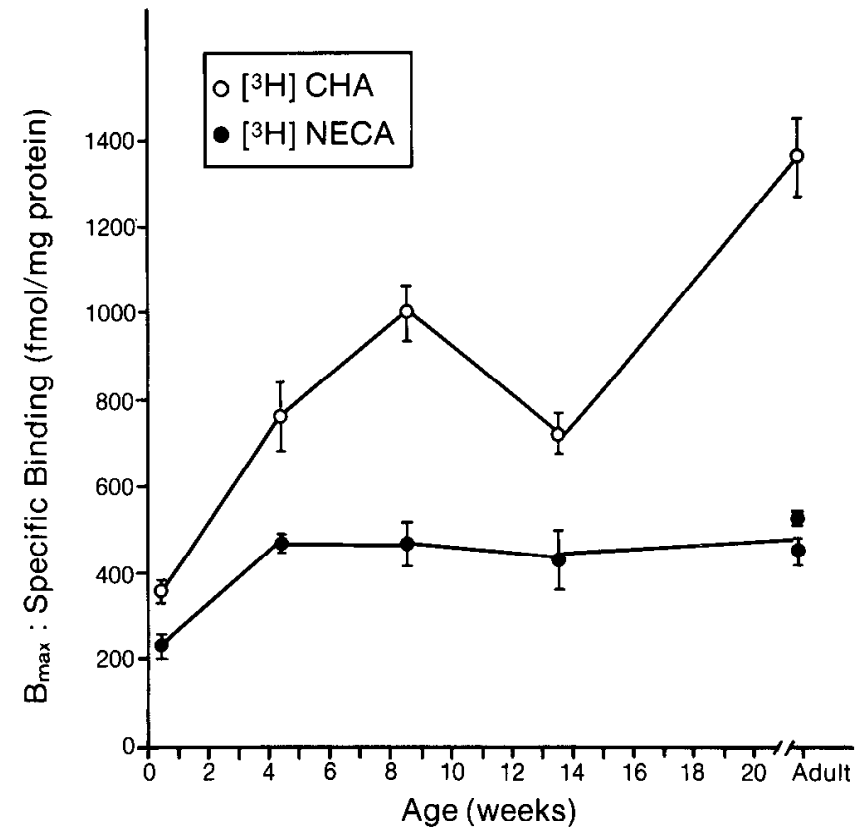

Figure 6. $B_{\max }$ values for different postnatal ages for ${ }^{3} \mathrm{H}-\mathrm{CHA}$ and ${ }^{3} \mathrm{H}-$ NECA binding sites. All incubations were at $23^{\circ} \mathrm{C}$ for $120 \mathrm{~min}$.

alternate sections processed for cytochrome c oxidase. Cytochrome c oxidase labels layer 4 most densely in cat visual cortex (Wong-Riley, 1979), offering a convenient laminar landmark with which to identify laminar patterns of receptor binding. In the adult cat, ${ }^{3} \mathrm{H}-\mathrm{CHA}$ (Fig. $3 A$ ) showed the densest binding in the supragranular layers (layers $1-3$ ). Moderate binding was also seen in the upper portion of layer 5. ${ }^{3} \mathrm{H}-\mathrm{NECA}$ labeled binding sites with essentially the same laminar distribution as that of ${ }^{3} \mathrm{H}-\mathrm{CHA}$ in the adult cat cortex (Fig. $3 B$ ).

\section{Postnatal development of ${ }^{3} \mathrm{H}-\mathrm{CHA}$ and ${ }^{3} \mathrm{H}-\mathrm{NECA}$ binding patterns}

Figure 4 illustrates the laminar distribution of ${ }^{3} \mathrm{H}-\mathrm{CHA}$ binding sites in kittens of various postnatal ages. The illustrations shown here have been photographed from the original autoradiograms at the same contrast level in order to allow direct comparisons among the different panels of Figure 4 . At 3,15, or $30 \mathrm{~d}$ after birth (panels $A-C$ ), layers 5-6 were most densely labeled, while the superficial cortical layers were relatively lightly labeled. By $60 \mathrm{~d}$ of age, the deep cortical layers were still labeled, but moderate binding had appeared in the superficial layers as well, resulting in a relatively laminarly homogeneous, albeit slightly patchy, binding pattern. By 95 d postnatal (panel $E$ ), the adult binding pattern became more apparent: Layers 1-3 exhibited dense binding, with layers 4-6 much lighter in comparison. In the adult, ${ }^{3} \mathrm{H}$-CHA strongly labeled layers $1-3$, with an additional sublayer in layer 5 (Fig. $4 F$ ), a pattern very different from that of the young kittens (Fig. 4, $A-C$ ).

${ }^{3} \mathrm{H}-\mathrm{NECA}$ binding shows a developmental pattern (Fig. 5) similar to that of ${ }^{3} \mathrm{H}-\mathrm{CHA}$. Again, the deep cortical layers were heavily labeled early in postnatal life. A more homogeneous binding pattern then developed, with the superficial layers becoming heavily labeled only late in postnatal development.

Figure 6 illustrates the changes in receptor number $\left(B_{\max }\right)$ during postnatal development for ${ }^{3} \mathrm{H}-\mathrm{CHA}$ and ${ }^{3} \mathrm{H}-\mathrm{NECA}$ binding sites. The number of ${ }^{3} \mathrm{H}-\mathrm{CHA}$ binding sites increased more than 3 -fold from low early values to adulthood. ${ }^{3} \mathrm{H}$-NECA binding increased until $30 \mathrm{~d}$ postnatally, remaining relatively constant thereafter.

Figure 7 shows $K_{\mathrm{d}}$ values during postnatal development for

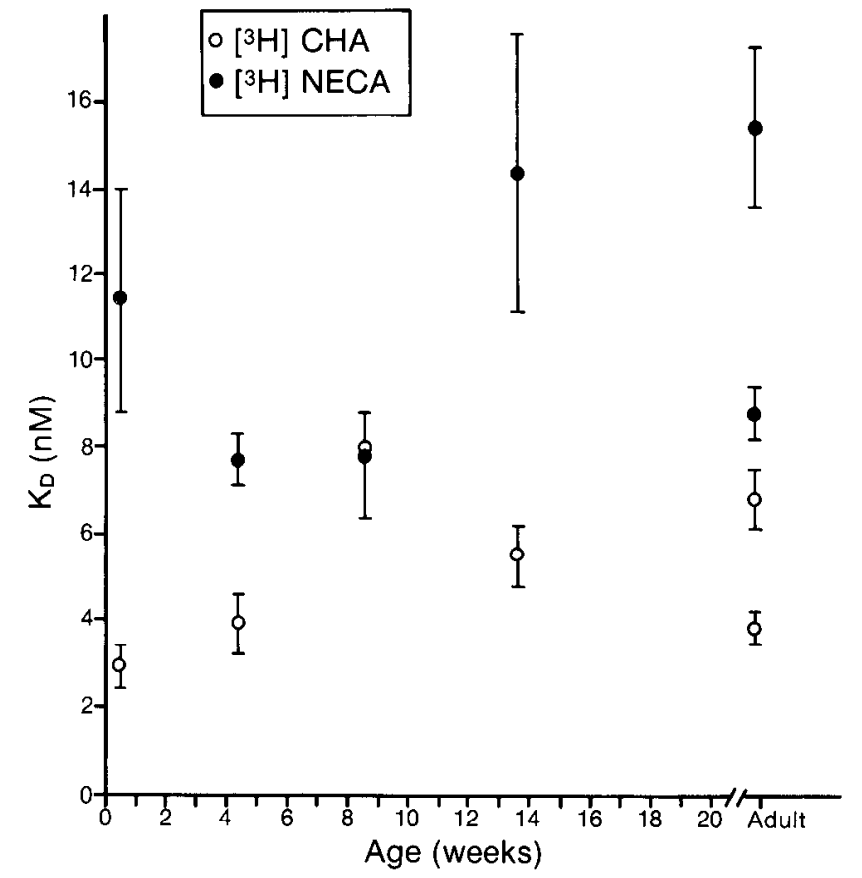

Figure 7. $K_{\mathrm{d}}$ values for different postnatal ages for ${ }^{3} \mathrm{H}-\mathrm{CHA}$ and ${ }^{3} \mathrm{H}-$ NECA binding sites. Incubation as in Figure 6.

both populations of binding sites. ${ }^{3} \mathrm{H}$-CHA showed a generally constant $K_{\mathrm{d}}$ during postnatal development. ${ }^{3} \mathrm{H}-\mathrm{NECA} K_{\mathrm{d}}$ values were quite variable but showed no clear trend during development.

\section{${ }^{3} \mathrm{H}-\mathrm{CH} A$ and ${ }^{3} \mathrm{H}-\mathrm{NECA}$ binding in other cortical and subcortical areas}

Studies of other receptors in cat and raccoon cortex reveal that receptor binding in primary sensory cortices is often denser and can show different lamination patterns than that in adjacent association cortices (Sampson et al., 1984; Shaw et al., 1984a). ${ }^{3} \mathrm{H}-\mathrm{CHA}$ and ${ }^{3} \mathrm{H}-\mathrm{NECA}$ binding in cat visual cortex likewise follows this pattern: Areas 17 and 18 have denser binding and more distinct lamination than nearby association cortex. Similarly, auditory cortex shows a highly laminar-specific binding pattern, with the highest binding densities in the supragranular laminae (data not shown). Binding also becomes less dense and more homogeneous across cortical layers in nonsensory cortical areas. Figure 8 illustrates a clear transition between the binding pattern in the ventral-most part of the striate cortex and that of the cingulate cortex.

${ }^{3} \mathrm{H}-\mathrm{CHA}$ and ${ }^{3} \mathrm{H}-\mathrm{NECA}$ have similar distributions in subcortical structures. Stratum oriens and stratum radiatum of the CA1 to CA3 fields of the hippocampus label densely. The subiculum and the inner molecular layers of the dentate gyrus also label densely for both ligands. The lateral geniculate nucleus (LGN) shows moderate and homogeneous binding in the cell layers, with the interlaminar zones relatively free of label. The medial geniculate nucleus labels moderately with some inhomogeneities. Both inferior and superior colliculi show low-moderate binding in the superficial layers only. Figure 8 shows ${ }^{3} \mathrm{H}$-CHA binding sites in the cat diencephalon midbrain to illustrate adenosine receptor distribution in some of the regions mentioned above.

\section{Discussion}

The identification of the ${ }^{3} \mathrm{H}-\mathrm{CHA}$ binding site in the cat visual cortex as an $A_{1}$-adenosine receptor seems relatively straightfor- 

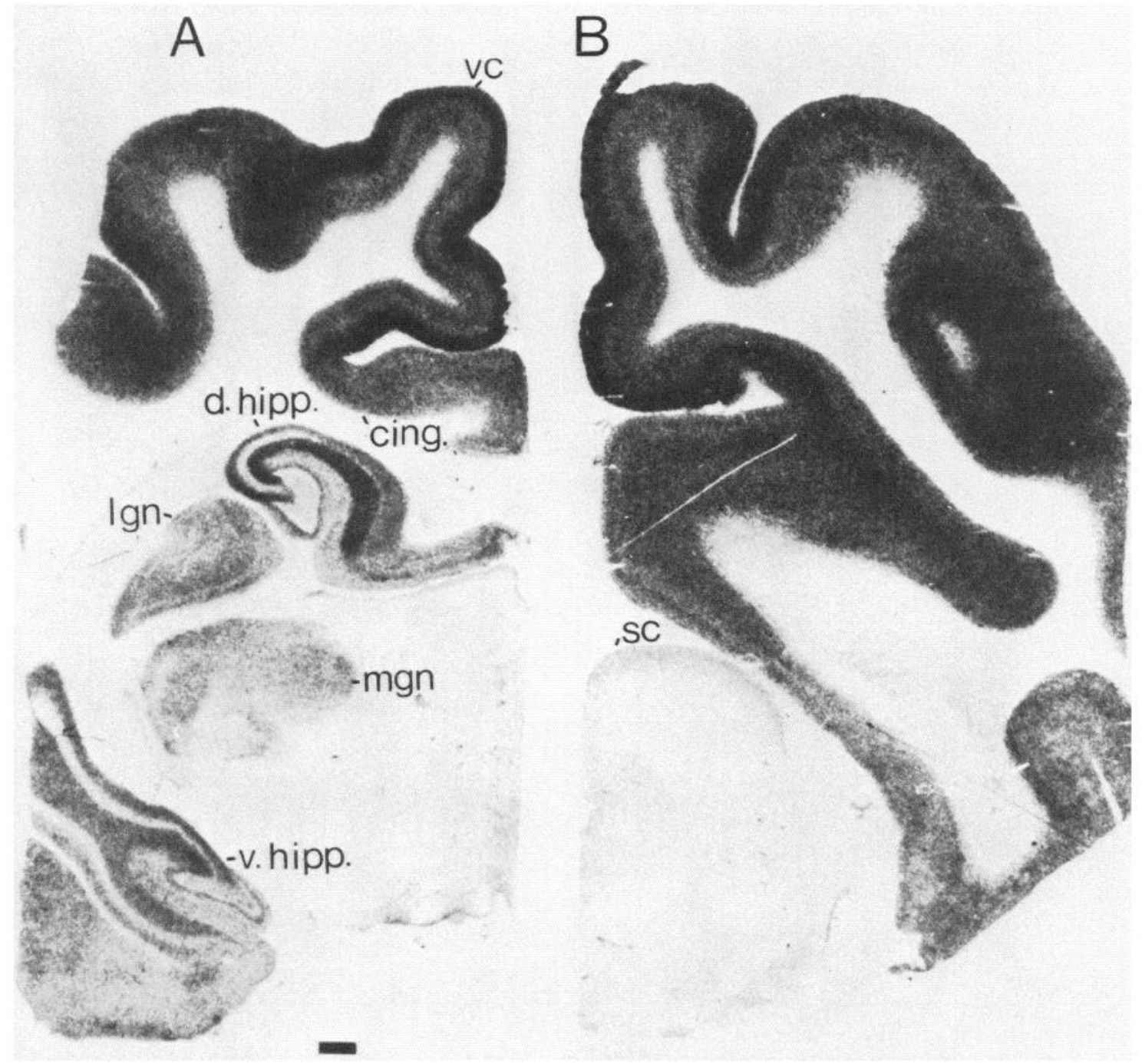

Figure 8. Montage of 2 coronal sections of cat diencephalon midbrain and cortex are used to illustrate ${ }^{3} \mathrm{H}-\mathrm{CHA}$ binding in the visual cortex and other cortical and subcortical areas. The sections were incubated with $26 \mathrm{nM}{ }^{3} \mathrm{H}-\mathrm{CHA}$ for $120 \mathrm{~min}$ at $23^{\circ} \mathrm{C}$. Note in general the dense binding in cortex compared with most of the diencephalon. A, The most densely labeled diencephalic areas are the hippocampus (hipp.; see text for further description) and the lateral and medial geniculate bodies (lgn, $m g n$ ). A clear laminar difference is observable between the binding in visual cortex $(v c)$ and cingulate cortex (cing.). B, Low to moderate binding is observed in the superficial layers of the superior colliculus (sc). Film exposure, $14 \mathrm{~d}$. Calibration bar, $1 \mathrm{~mm}$. Dorsal is up, medial is right in $A$ and left in $B$.

ward. The binding pattern is similar to that reported for $\mathrm{A}_{1}$-adenosine receptors in the cat (Aoki, 1985); in rat cortex the binding pattern differs (Goodman and Snyder, 1982; Goodman et al., 1983). Additionally, the $K_{\mathrm{d}}$ and displacement characteristics are generally similar to those reported for $A_{1}$-adenosine receptors previously described (Aoki, 1985; Bruns et al., 1980; Goodman and Snyder, 1982), although Aoki (1985) reports 2 distinct binding sites in cat visual cortex using ${ }^{3} \mathrm{H}-\mathrm{CHA}$.

The identification of the cortical ${ }^{3} \mathrm{H}-\mathrm{NECA}$ binding site is more problematic. ${ }^{3} \mathrm{H}-\mathrm{NECA}$ binds with lower affinity than ${ }^{3} \mathrm{H}-$ $\mathrm{CHA}$, in agreement with reports of $\mathrm{A}_{2}$-adenosine receptor binding in other preparations (Bruns et al., 1980). A Hill plot of the saturation binding data suggests the existence of a single population of binding sites, although ${ }^{3} \mathrm{H}-\mathrm{NECA}$ in other preparations is reported to bind to both $A_{1}$ and $A_{2}$ adenosine sites (Fredholm, 1982; Snyder, 1985). The higher $K_{\mathrm{d}}$ for ${ }^{3} \mathrm{H}-\mathrm{NECA}$ is attributable to an almost 3-fold slower association rate constant. The dissociation rate constants for the 2 ligands are approximately the same, suggesting that the differences in $B_{\max }$ $\left({ }^{3} \mathrm{H}-\mathrm{CHA}\right.$ nearly 3 times that of $\left.{ }^{3} \mathrm{H}-\mathrm{NECA}\right)$ are due to different numbers of distinct binding sites. If ${ }^{3} \mathrm{H}-\mathrm{NECA}$ were binding to both $\mathrm{A}_{1}$ and $\mathrm{A}_{2}$ sites, we would expect a higher $B_{\max }$ than for ${ }^{3} \mathrm{H}-\mathrm{CHA}$, unless the $K_{-1}$ were appreciably faster, which is not the case. In addition, the postnatal time course of variation in $B_{\max }$ is quite different for the 2 ligands. Taken together, these data argue for a cortical ${ }^{3} \mathrm{H}-\mathrm{NECA}$ binding site distinct from the $A_{1}$ site labeled by ${ }^{3} \mathrm{H}-\mathrm{CHA}$. The difficulty with this interpretation is that the order of effectiveness for the various displacer substances tested is very similar, although not identical, for the 2 ligands (Figs. 1; 2; Table 1). Previous reports in other systems have indicated major differences in displacer potencies at the 2 sites. Another difficulty is the nearly identical laminar distribution of ${ }^{3} \mathrm{H}-\mathrm{CHA}$ and ${ }^{3} \mathrm{H}-\mathrm{NECA}$ binding patterns. These 2 reservations, especially the first, raise questions concerning the identification of the ${ }^{3} \mathrm{H}$-NECA binding site in the cat cortex as the $\mathrm{A}_{2}$-adenosine receptor described by other investigators. Further experiments are required to establish definitively whether ${ }^{3} \mathrm{H}-\mathrm{NECA}$ binds to the same sites as does ${ }^{3} \mathrm{H}-\mathrm{CHA}$ or to a distinct subclass of adenosine receptors in cat visual cortex.

The binding patterns exhibited for adenosine receptors in the 

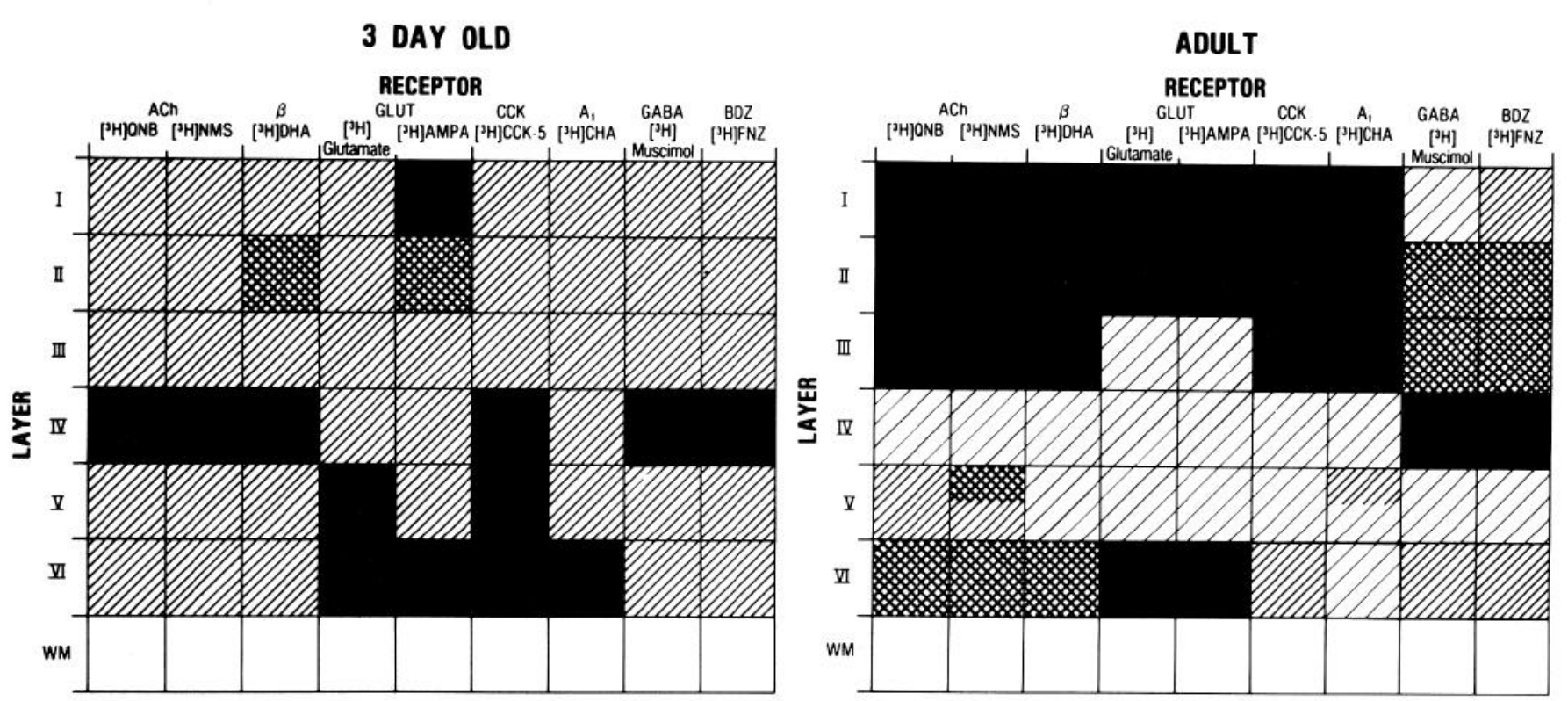

relative Binding DeNSITIES

VERY HIGH HIGH MOderate LIGHT No $\square$

Figure 9. Schematic representation of the laminar binding patterns for 9 receptor populations in 3-d-old and adult cats. Note that binding densities are given only in qualitative values: very high, high, moderate, low, and no binding. Using this scale, it is possible to compare the relative binding density for any receptor population across the cortical laminae but not to compare different receptors to each other or the 3-d-old to the adult. Abbreviations: ACh receptors (acetylcholine, muscarinic sites) were labeled using ${ }^{3} \mathrm{H}$-quinuclidinyl benzilate $(Q N B)$ and ${ }^{3} \mathrm{H}-N$-methyl-scopolamine ( NMS ; Shaw et al., 1984a with carbachol competition); $\beta$-adrenergic receptors were labeled using ${ }^{3} \mathrm{H}$-dihydroalprenolol (DHA; Shaw et al., $1984 \mathrm{c}$ ); $N$-methyl-D-aspartate $(N M D A)$ kainate and quisqualate receptors were labeled using ${ }^{3} \mathrm{H}$-L-glutamate (C. Shaw and M. Cynader, unpublished observations); quisqualate receptors were labeled using ${ }^{3} \mathrm{H}$-amino-3-hydroxy-5-methylisoxazole-4-propionic acid ( $A M P A$; C. Shaw and M. Cynader, unpublished observations); cholecystokinin $(C C K)$ receptors were labeled using ${ }^{3} \mathrm{H}$-pentagastrin $(C C K$-5; Shaw and Cynader, $1985 \mathrm{a})$; GABA receptors were labeled using ${ }^{3} \mathrm{H}$-muscimol (Shaw et al., 1984b); and benzodiazepine (BDZ) receptors were labeled with ${ }^{3} \mathrm{H}$-flunitrazepam (FNZ); for further details, see Shaw et al. (1984c).

adult cat resemble those previously described for muscarinic ACh receptors (Shaw et al., 1984a), cholecystokinin receptors (Shaw and Cynader, 1985), $\beta$-adrenergic receptors (Shaw et al., $1984 \mathrm{c}$ ), and, to a lesser extent, binding sites labeled by ${ }^{3} \mathrm{H}-\mathrm{L}-$ glutamate and ${ }^{3} \mathrm{H}$-amino-3-hydroxy-5-methylisoxazole-4-propionic acid (AMPA) (C. Shaw and M. Cynader, unpublished observations).

Both ${ }^{3} \mathrm{H}-\mathrm{CHA}$ and ${ }^{3} \mathrm{H}-\mathrm{NECA}$ binding sites show alterations in their laminar binding patterns during postnatal development. Similar changes, or even reversals, of the original neonatal laminar binding pattern have been found in the majority of cortical receptor populations we have studied to date (Shaw and $\mathrm{Cy}$ nader, 1985; Shaw et al., 1984a, b, 1985). These data are summarized in schematic form for young kittens and adult cats in Figure 9.

Most of the previously studied receptors that have exhibited changes in developmental laminar binding patterns (muscarinic/ cholinergic, cholecystokinin, and $\beta$-adrenergic binding sites) have shown dense concentrations in layer 4 initially, and subsequent alterations to favor the superficial and/or deep layers. Other receptors (GABA, benzodiazepine) are concentrated in layer 4 at all postnatal ages. Adenosine binding sites differ in that layers 5 and 6 show the densest binding initially, layers $1-3$ are most heavily labeled in the adult, and layer 4 is not a zone of highest concentration at any stage of development. The pattern of alteration of binding sites (from deep to superficial cortical layers) parallels that previously reported for the ontogeny of neurons in the different cortical layers (Rakic, 1974). The relative absence of adenosine receptors in layer 4 at all ages suggests that adenosine does not exert its effects at the first stage of cortical information processing, but rather that it acts on higher-order cortical functions. This reduced presence in layer 4 also characterizes muscarinic acetylcholinergic binding sites of the adult cat (Shaw et al., 1984a), and it is interesting to note that these 2 "modulatory" substances seem to have similar effects on cortical EEG and behavioral arousal. It has long been known that administration of the muscarinic antagonist scopolamine results in cortical EEG synchronization in the absence of behavioral sleep (Steriade and Hobson, 1976). Administration of L-PIA, an adenosine agonist, results in behavioral manifestations of sleep, but with a desynchronized cortical EEG (Meltzer et al., 1984).

As was the case for several other receptors studied in cat visual cortex (Jonsson and Kasamatsu, 1983; Shaw and Cynader, 1985, unpublished observations; Shaw et al., 1984a-c; Wilkinson et al., 1983) and the cortex of other species (Candy and Martin, 1979; Pittman et al., 1980), adenosine receptor density $\left(B_{\max }\right)$ was initially low but increased during postnatal development. ${ }^{3} \mathrm{H}-\mathrm{CHA}$ binding density peaked in adulthood, while ${ }^{3} \mathrm{H}-\mathrm{NECA}$ binding density peaked at $30 \mathrm{~d}$ postnatally. Geiger et al. (1984) have reported an increase in the number of $A_{1}$-adenosine receptors during postnatal development in rat cerebral cortex.

$K_{\mathrm{d}}$ values for the 2 binding sites showed some developmental variations, but no clear or significant trends were seen, unlike those observed for rat adenosine receptors (Geiger et al., 1984) and for other cortical receptor populations (Shaw et al., 1984c, 1985). Of the other receptors studied to date in cat visual cortex, only the $\beta$-adrenergic receptors, also purported to be modulatory in action, show no consistent $K_{\mathrm{d}}$ changes during postnatal development (Shaw et al., 1985).

The issue of the cellular location of adenosine receptors is a subject of some controversy. Goodman et al. (1983) have sug- 
gested a presynaptic locus for $A_{1}$-adenosine receptors in rat superior colliculus but not for the LGN or visual cortex. In other preparations, adenosine receptors are probably postsynaptic (Geiger et al., 1984). We have examined these issues in a preliminary way in adult cats subjected to unilateral enucleation (3 month survival), unilateral decortication (2-3 week survival), or unilateral LGN lesion ( 2 week survival). In no case have we noted a significant change in adenosine receptor density or pattern of binding in either the LGN (following enucleation), superior colliculus, or visual cortex. Results were the same whether ${ }^{3} \mathrm{H}-\mathrm{CHA}$ or ${ }^{3} \mathrm{H}-\mathrm{NECA}$ was employed as a ligand. These results suggest that if adenosine receptors are associated with the retinogeniculate, retinocollicular, geniculocortical, or callosal pathways, then they are not presynaptic in location, at least not in the cat. Any presynaptic loci for adenosine receptors in cat visual cortex are thus likely to arise from intracortical circuits.

The functional role of adenosine receptors within the cortex remains unclear. The evidence that adenosine modulates the synaptic release of a wide variety of different substances (Harms et al., 1979; Hollins and Stone, 1980; Michaelis et al., 1979; Snyder, 1985) allows for a number of different roles. It is interesting, in view of recent findings, that adenosine blocks relcase of glutamate from cortical slices (Dolphin and Archer, 1983), and that adenosine receptors and binding sites labeled by $\mathrm{L}$-glutamate (Monaghan et al., 1985) show somewhat similar laminar distributions within the visual cortex (C. Shaw and $M$. Cynader, unpublished observations). We note, however, that the distributions of adenosine receptors and glutamate-related binding sites both alter their laminar distribution during development and that these patterns of changes are clearly different. The developmental patterns, which are specific and different for these, and other, receptors may allow for maximum modulation of the functions of any particular neurotransmitter system by adenosine at a specific time during postnatal development.

The identification of adenosine receptors in cat visual cortex and the description of their laminar binding pattern and ontogenesis add important information to the broadening picture of the chemical circuitry of this region of the brain. In conjunction with the description of the other receptor populations thus far studied, these data reveal a complex system with the possibility of multiple interactions among different neurotransmitters. Unraveling these interactions promises to be a major task for the future.

\section{References}

Aoki, C. (1985) Development of the $A_{1}$ adenosine receptors in the visual cortex of cats, dark reared and normally reared. Dev. Brain Res. 22: 125-134.

Barnes, E. M., and K. G. Thampy (1982) Subclasses of adenosine receptors in brain membranes from adult tissue and from primary cultures of chick embryo. J. Neurochem. 39: 647-652.

Bruns, R. F., J. W. Daly, and S. H. Snyder (1980) Adenosine receptors in brain membranes: Binding of $\mathrm{N}^{6}$-cyclohexyl-[ $\left.{ }^{3} \mathrm{II}\right]$ adenosine and 1,3-diethyl-8- $\left[{ }^{3} \mathrm{H}\right]$ phenylxanthine. Proc. Natl. Acad. Sci. USA 77: 5547-5551.

Burnstock, G. (1978) A basis for distinguishing two types of purinergic receptor. In Cell Membrane Receptors for Drugs and Hormones, $\mathbf{R}$. W. Straub and L. Bolis, eds., pp. 107-118, Raven, New York.

Candy, J. M., and I. C. Martin (1979) The postnatal development of the benzodiazepine receptor in the cerebral cortex and cerebellum of the rat. J. Neurochem. 32: 655-658.

Cynader, M., B. N. Timney, and D. E. Mitchell (1980) Period of susceptibility of kitten visual cortex to the effects of monocular deprivation extends beyond six months of age. Brain Res. 191: 545550.

Dolphin, A. C., and E. R. Archer (1983) An adenosine agonist inhibits and a cyclic AMP analogue enhances the release of glutamate but not GABA from slices of rat dentate gyrus. Neurosci. Lett. 43: 49-54.

Emson, P. C., and S. P. Hunt (1979) Anatomical chemistry of the cerebral cortex. In The Organisation of the Cerebral Cortex, F. O. Schmitt, F. G. Worden, G. Adelman, and S. C. Dennis, eds., pp. 325345, MIT Press, Cambridge, MA.

Fredholm, B. B. (1982) Adenosine receptors. Med. Biol. 60: 289-293.

Fredholm, B. B., and P. Hedqvist (1980) Modulation of neurotransmission by purine nucleotides and nucleosides. Biochem. Pharmacol. 29: $1635-1643$.

Geiger, J. D., F. S. Labella, and J. I. Nagy (1984) Characterization and localization of adenosine receptors in rat spinal cord. J. Neurosci. 4: $2303-2310$

Ginsborg, B. L., and G. D. S. Hirst (1972) The effects of adenosine on the release of the transmitter from the phrenic nerve of the rat. $J$. Physiol. (Lond.) 244: 629-645.

Goodman, R. R., and S. H. Snyder (1982) Autoradiographic localization of adenosine receptors in rat brain using $\left[{ }^{3} \mathrm{H}\right]$ cyclohexyladenosine. J. Neurosci. 2: 1230-1241.

Goodman, R. R., M. J. Kuhar, L. Hester, and S. H. Snyder (1983) Adenosine receptors: Autoradiographic evidence for their location on axon terminals of excitatory neurons. Science 220: 967-969.

Harms, H. H., G. Wardeh, and A. H. Mulder (1979) Effects of adenosine on depolarization-induced release of various radiolabeled neurotransmitters from slices of rat corpus striatum. Neuropharmacology 18: 577-580.

Hollins, C., and T. W. Stone (1980) Adenosine inhibition of $\gamma$-aminobutyric acid release from slices of rat cerebral cortex. Br. J. Pharmacol. 69: 107-112.

Hubel, D. H., and T. N. Wiesel (1962) Receptive fields, binocular interaction and functional architecture in the cat's visual cortex. $\mathbf{J}$. Physiol. (Lond.) 160: 106-154.

Hubel, D. H., and T. N. Wiesel (1970) The period of susceptibility to the physiological effects of unilateral eye closure in kittens. J. Physiol. (Lond.) 206: 419-436.

Jonsson, G., and T. Kasamatsu (1983) Maturation of monoamine neurotransmitters and receptors in cat occipital cortex during postnatal critical period. Exp. Brain Res. 50: 449-458.

Londos, C., and J. Wolff (1977) Two distinct adenosine sensitive sites on adenylate cyclase. Proc. Natl. Acad. Sci. USA 74: 5482-5486.

Londos, C., D. M. F. Cooper, and J. Wolff (1980) Subclasses of external adenosine receptors. Proc. Natl. Acad. Sci. USA 77: 2551-2554.

Lowry, O. H., N. J. Rosebrough, A. L. Farr, and R. J. Randall (1951) Protein measurement with the Folin phenol reagent. J. Biol. Chem. 193: 265-275.

Lund, J. S. (1973) Organisation of neurons in the visual cortex, area 17, of the monkey (Macaca mulatta). J. Comp. Neurol. 147: 455496.

Meltzer, L. T., F. W. Marcoux, L. Christofferson, J. Cordon, and K. A. Serpa (1984) Comparison of the effects of an adenosine agonist and pentobarbital on cortical blood flow and EEG in rats. Soc. Neurosci. Abstr. 10: 1143.

Michaelis, M. L., E. K. Michaelis, and S. L. Myers (1979) Adenosine modulation of synaptosomal dopamine release. Life Sci. 24: 20832092.

Monaghan, D. T., D. Yao, and C. W. Cotman (1985) $\mathrm{L}\left[{ }^{3} \mathrm{H}\right]$ glutamate binds to kainate-, NMDA- and AMPA-sensitive binding sites: An autoradiographic analysis. Brain Res. 340: 378-383.

Murphy, K. M. M., and S. H. Snyder (1982) Heterogeneity of adenosine $A_{1}$ receptor binding in brain tissue. Mol. Pharmacol. 22: 250257.

Olson, C. R., and R. D. Freeman (1980) Profile of the sensitive period for monocular deprivation in kittens. Exp. Brain Res. 39: 17-21.

Parnavelas, J., and J. K. McDonald (1983) The cerebral cortex. In Chemical Neuroanatomy, P. C. Emson, ed., pp. 505-549, Raven, New York.

Phillis, J. W., and G. K. Kostopoulos (1975) Adenosine as a putative transmitter in the cerebral cortex. Studies with potentiators and antagonists. Life Sci. 17: 1085-1094.

Phillis, J. W., and P. H. Wu (1981) The role of adenosine and its nucleotides in central synaptic transmission. Prog. Neurobiol. 16: 187-239.

Pittman, R. N., K. P. Minneman, and P. B. Molinoff (1980) Ontogeny of $\beta_{1}$ and $\beta_{2}$-adrenergic receptors in rat cerebellum and cerebral cortex. Brain Res. 188: 357-368.

Rakic, P. (1974) Ncurons in rhesus monkcy visual cortcx: Systcmatic relation between time of origin and eventual disposition. Science 183: $425-427$. 
Ribeiro, J. A. (1979) Purinergic modulation of transmitter release. J. Theor. Biol. 80: 259-270.

Ribeiro, J. A., A. M. Sa-Almeida, and J. M. Namorado (1979) Adenosine and adenosine triphosphate decrease ${ }^{45} \mathrm{Ca}$ uptake by synaptosomes stimulated by potassium. Biochem. Pharmacol. 28: 1297-1300.

Sampson, S. M., C. Shaw, and D. D. Rasmusson (1984) Discrete zones of increased muscarinic acetylcholine receptors in raccoon somatosensory cortex following digit removal. Physiol. Can. 15(3): 178.

Shaw, C., and M. Cynader (1985) Alterations in the laminar distribution of pentagastrin binding sites in cat visual cortex during postnatal development. Dev. Brain Res. 20: 132-136.

Shaw, C., M. C. Needler, and M. Cynader (1984a) Ontogenesis of muscarinic acetylcholine binding sites in cat visual cortex: Reversal of specific laminar distribution during the critical period. Dev. Brain Res. 14: 295-299.

Shaw, C., M. C. Needler, and M. Cynader (1984b) Ontogenesis of muscimol binding sites in cat visual cortex. Brain Res. Bull. 13: 331334.

Shaw, C., M. C. Needler, M. Wilkinson, C. Aoki, and M. Cynader (1984c) Alterations in receptor number, affinity, and laminar distribution in cat visual cortex during the critical period. Prog. Neuropsychopharmacol. Biol. Psychiatr. 8: 627-634.

Shaw, C., M. C. Needler, M. Wilkinson, C. Aoki, and M. Cynader (1985) Modification of neurotransmitter receptor sensitivity in cat visual cortex during the critical period. Dev. Brain Res. 22: 67-73.

Snyder, S. H. (1984) Drug and neurotransmitter receptors in the brain. Science 224: 22-31.

Snyder, S. H. (1985) Adenosine as a neuromodulator. Annu. Rev. Neurosci. 8: 103-124.
Steriade, M., and J. A. Hobson (1976) Neuronal activity during the sleep-wakefulness cycle. Prog. Neurobiol. 6: 155-176.

Stone, T. W. (1981) Physiological roles for adenosine and adenosine 5 -triphosphate in the nervous system. Neuroscience 6: 523-555.

Stone, T. W. (1982) Purine receptors involved in the depression of neuronal firing in cerebral cortex. Brain Res. 248: 367-370.

Stone, T. W., and M. N. Perkins (1979) Is adenosine the mediator of opiate action on neural firing rate? Nature 281: 227-228.

Tusa, R. J., L. A. Palmer, and A. C. Rosenquist (1981) Multiple cortical visual areas; visual field topography in the cat. In Cortical Sensory Organization, Vol. 2, C. N. Woolsey, ed., pp. 1-31, Humana, Clifton, NJ.

Van Calker, D., M. Muller, and B. Hambrecht (1979) Adenosine regulates via two types of receptors the accumulation of cyclic AMP in cultured brain cells. J. Neurochem. 33: 999-1005.

Wilkinson, M., C. Shaw, I. Khan, and M. Cynader (1983) Ontogenesis of $\beta$-adrenergic binding sites in kitten visual cortex and the effects of visual deprivation. Dev. Brain Res. 7: 349-352.

Wong-Riley, M. (1979) Changes in the visual system of monocularly sutured or enucleated cats demonstrable with cytochrome oxidase histochemistry. Brain Res. 171: 11-28.

Wu, P. H., J. W. Phillips, and A. S. Bender (1981) Do benzodiazepines bind at adenosine uptake sites in CNS? Life Sci. 28: 1023-1031.

Young, W. S., and M. J. Kuhar (1979) A new method for receptor autoradiography: $\left[{ }^{3} \mathrm{H}\right]$ opioid receptors in rat brain. Brain Res. 179: $255-270$.

Zivin, J. A., and D. R. Waud (1982) How to analyze binding, enzyme and uptake data: The simplest case, a single phase. Life Sci. 30: 14071422 . 